Memahami Islam... Oleh: M.Arif Khoiruddin

\title{
MEMAHAMI ISLAM DALAM PERSPEKTIF FILOSOFIS
}

\author{
Oleh: \\ M. Arif Khoiruddin \\ arif.khoiruddin84@gmail.com \\ Institut Agama Islam Tribakti (IAIT) Kediri
}

\begin{abstract}
Abstrak
Memahami Islam melalui pendekatan filosofis dimaksudkan agar memberi makna terhadap sesuatu yang dijumpai, menangkap hikmah, hakikat atau inti yang terkandung dalam ajaran Islam sehingga dalam melakukan amal ibadah tidak merasa hampa, kekeringan spiritual serta menimbulkan kebosanan dalam menjalankannya. Selain itu dapat meningkatkan sikap, penghayatan dan daya spiritualitas sehingga tidak terjebak dalam pemahaman agama yang sekedar formalistik dan tidak menemukan nilai-nilai didalamnya. Pendekatan filosofis diibaratkan sebagai pisau analisis untuk membedah Islam secara mendalam, integral dan komprehensif untuk melahirkan pemahaman dan pemikiran tentang Islam yang senantiasa relevan pada setiap waktu dan ruang atau shalih fi kulli zaman wal makan. Pentingnya pendekatan ini, pendekatan filosofis juga digunakan dalam memahami berbagai bidang lainnya selain agama. Misalnya filsafat hukum Islam, filsafat sejarah, filsafat kebudayaan, filsafat ekonomi, dan lain sebagainya. Meskipun secara teoretis memberikan harapan dan kesejukan, namun secara luas belum dapat dipahami dan diterima kecuali oleh sekelompok kecil saja, terutama bagi kaum tradisionalis formalistis yang cenderung memahami agama terbatas pada ketetapan melaksanakan aturan-aturan formalistik dari pengalaman agama.
\end{abstract}

Kata Kunci: Islam, Pendekatan Filosofis. 


\section{Pendahuluan}

Mempelajari agama Islam dari berbagai sudut pandang diperlukan pendekatan yang secara operasional konseptual dapat memberikan pandangan bahwa Islam itu sangat luas. Kajian studi Islam sebagai disiplin ilmu sudah dimulai sejak lama, studi ini mempunyai akar yang kokoh di kalangan sarjana muslim dalam tradisi keilmuan tradisional. Mereka berupaya menginterpretasikan tentang Islam terus berlanjut hingga sekarang. Dalam Islamic Studies terdapat berbagai pendekatan yang saling melengkapi dan mengisi antara satu dengan yang lain seperti pendekatan teologis, sosiologis, kebudayaan, historis termasuk melalui pendekatan secara filosofis.

Dalam agama Islam ada dua inti dari segala sesuatu yaitu sesuatu yang bersifat Ketuhanan atau ilahi yang bersumber dari Al-Qur'an dan As-Sunnah dan ini bersifat mutlak. Sedangkan yang kedua bersifat kemanusiaan yang berbentuk pemahaman manusia atau fiqh, kesan yang muncul dari berbagai teks yang dibaca dan dialami atau pengalaman atau latar belakang pendidikan, ekonomi, sosial, psikologi dan lain sebagainya dan ini bersifat relatif.

Filsafat sebagai salah satu pendekatan keilmuan sebagaimana halnya cabang keilmuan yang lain, sering kali dikaburkan dan dirancukan dengan paham-paham atau aliranaliran tertentu misalnya aliran pragmatisme, eksistensialisme, rasionalisme, empirisme, materialisme dan lain-lain. Namun ada perbedaan antara kedua wilayah tersebut, untuk wilayah pertama lebih bersifat keilmuan, terbuka, dinamis, inklusif seperti lebih bersifat pure sciences, tidak terkotak-kotak dan tidak tersekatsekat. Sedangkan pada wilayah kedua lebih bersifat ideologis, tertutup, statis, eksklusif seperti halnya applied sciences, seolaholah tersekat dan terkotak-kotak oleh perbedaan kultur, tradisi, latar belakang pergumulan sosial dan bahasa ${ }^{1}$

Mengkaji Islam secara filosofis akan menjadikan segala sesuatu disandarkan kepada konteks, baik berupa kebaikan sosial, local wisdom, social impact, rasionalitas dan lain-lain,

${ }^{1}$ M. Amin Abdullah, Antologi Studi Islam: Teori \& Metodologi (Yogyakarta: Sunan Kalijaga Press, 2000), h. 8. 
serta bersandar pada analisis rasio manusia yang akan bersifat relatif. Kegiatan berfilsafat adalah kegiatan berpikir secara mendalam, dilakukan sedemikian rupa hingga dicari sampai ke batas akal tidak sanggup lagi. Berpikir secara radikal, sampai ke akar-akarnya sehingga tidak ada lagi yang tersisa. Secara sistematik, dilakukan secara teratur dengan menggunakan metode berpikir tertentu, bersifat universal, tidak dibatasi hanya satu kepentingan kelompok tertentu, tetapi lebih menyeluruh. ${ }^{2}$

Filsafat dengan segala bentuk usaha yang dilakukan untuk mencari dan mengetahui hakikat kebenaran dari segala sesuatu, ketika digunakan dalam mengkaji Islam tentu tidak selalu mencapai hasil yang diharapkan dan bisa maksimal akan tetapi yang terpenting adalah adanya upaya memanfaatkan hasil usaha tersebut untuk membuat perubahan ke arah yang lebih baik. Manfaat yang bisa diperoleh ketika seseorang menggunakan pendekatan secara filosofis dalam mengkaji Islam adalah agar hikmah, hakikat dan inti dari ajaran agama dapat dipahami dan dimengerti dengan baik. Dapat memberi makna dan bisa mengambil hikmah terhadap segala sesuatu dilakukan yang merupakan bagian dari ajaran agama maupun yang dijumpainya seperti mengerjakan ibadah maupun perintah yang lain tidak mengalami kemunduran spiritualitas yang dapat menimbulkan kebosanan, akan tetapi dapat membentuk pribadi yang selalu berpikir kritis (critical thought), adanya kebebasan intelektual (intellectual freedom) dan membentuk pribadi yang toleran. ${ }^{3}$

\section{Pembahasan}

\section{Pengertian Filsafat}

Kata filsafat diambil dari bahasa Arab falsafah atau filsafat. Orang Arab sendiri mengambilnya dari bahasa Yunani terdiri dari kata philos dan Shopia. Philos artinya cinta dalam arti seluas-luasnya. Sedangkan kata Sophia artinya kebijaksanaan. Bijaksana berarti pandai, yakni mengerti dengan

2 Mark B. Woodhouse, A Preface to Philosophy (Belmont California: Wadsworth Publishing Company, 1984), h. 16-19.

${ }^{3}$ Omar Mohammad Al Toumy Al Syaibany, Filsafat Pendidikan Islam (Hoboken, NJ: JA Macfadden-Bartell Book, 1979), h. 35. 
mendalam. Dari segi bahasa dapat diambil pengertian filsafat berarti ingin mengerti dengan mendalam atau cinta kepada kebijaksanaan. ${ }^{4}$ Filsafat juga dapat diartikan mencari hakikat sesuatu, berusaha mencari sebab dan akibat serta berusaha menafsirkan pengalaman-pengalaman manusia. ${ }^{5}$

Dalam bahasa Arab dikenal kata hikmah dan hakim, kata ini bisa diterjemahkan dengan filsafat atau filosof. Kata hukkam al-Islam bisa berarti filsafat Islam. Hikmah adalah perkara tertinggi yang bisa dicapai oleh manusia dengan melalui alatalat tertentu yaitu akal dan metode-metode berpikirnya. ${ }^{6}$ Filsafat bukanlah hikmah akan tetapi cinta terhadap hikmah dan berusaha mendapatkan, memusatkan perhatian dan menciptakan sikap positif terhadapnya. Definisi ini juga digunakan dalam falsafah Islam. Filosof muslim berusaha mendapatkan sumber dari Al-Qur'an, seperti firman Allah dalam Surat Al-Baqarah: 269:

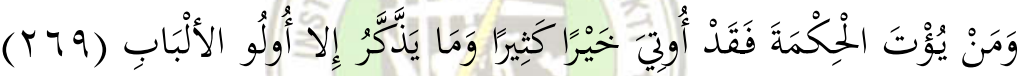

Terjemahnya: "Dan barangsiapa yang dianugerahi hikmah, ia benar-benar telah dianugerahi karunia yang banyak. dan hanya orang-orang yang berakallah yang dapat mengambil pelajaran."

Secara terminologi pengertian filsafat mempunyai pengertian bermacam-macam akan tetapi memiliki inti sari yang relatif sama. Menurut Endang Saifudin Anshari bahwa filsafat adalah hasil usaha manusia dengan kekuatan akal budinya untuk memahami (menyelami dan mendalami) secara radikal, integral dan universal hakikat sarwa yang ada (hakikat Tuhan, hakikat alam dan hakikat manusia) serta sikap manusia termasuk sebagai konsekuensi dari pemahamannya tersebut. ${ }^{7}$

${ }^{4}$ Endang Saifuddin, Kuliah Al-Islam, Pendidikan Agama Islam Di Perguruan Tinggi (Bandung: Pustaka Salman ITB, 1980), h. 13.

${ }^{5}$ Omar Mohammad Al Toumy Al Syaibany, Falsafah Pendidikan Islam (Hoboken, NJ: JA Macfadden-Bartell Book, 1979), h. 25.

6 Ahmad Hanafi, Islam Falsafah Agama (Jakarta: Bulan Bintang, 1973), h. 3.

7 Saifuddin, Kuliah Al-Islam, Pendidikan Agama Islam Di Perguruan Tinggi, h. 14. 
Menurut Harun Nasution bahwa definisi filsafat bermacam-macam antara lain; 1) pengetahuan hikmah; 2) pengetahuan tentang prinsip atau dasar-dasar; 3) mencari kebenaran; 4) membahas dasar-dasar dari apa yang dibahas dan lain-lain. Intinya filsafat adalah berpikir menurut tata tertib (logika) dengan bebas (tidak terikat pada tradisi, dogma dan sebagainya) dengan sedalam-dalamnya sehingga sampai ke dasar-dasar persoalan. ${ }^{8}$

Dari berbagai pendapat tersebut dapat dipahami bahwa istilah filsafat mengandung pengertian: 1) sebagai aktifitas berpikir murni atau kegiatan akal manusia dalam usaha untuk mengerti secara mendalam segala sesuatu (kesemestaan), pengertian filsafat di sini ialah berfilsafat. 2) sebagai produk kegiatan berpikir murni. Merupakan suatu wujud ilmu sebagai hasil pemikiran dan penyelidikan berfilsafat. Ini menunjukkan filsafat bukan hanya sekadar suatu aktifitas berpikir atau suatu proses dan suatu usaha tetapi mengandung kedua-duanya baik sebagai aktifitas akal manusia sebagai perbendaharaan sebagai wujud hasil pemikiran akal. Sebagai suatu ilmu filsafat merupakan ilmu istimewa yang mencoba menjawab persoalanpersoalan yang belum atau tidak dapat dijawab oleh ilmu pengetahuan biasa, karena persoalan-persoalan tersebut ada di luar jangkauan ilmu pengetahuan biasa. ${ }^{9}$ Sedangkan cabangcabang dari filsafat meliputi: ${ }^{10}$

1. Metafisika yaitu filsafat tentang hakikat yang ada dibalik fisika, tentang hakikat yang ada yag bersifat transenden, di luar atau di atas pengalaman manusia. bagian ini disebut juga dengan ontologi

2. Logika yaitu filsafat tentang pikiran yang benar dan salah

3. Etika yaitu filsafat tentang tingkah laku yang baik dan buruk

${ }^{8}$ Harun Nasution, Falsafah Agama (Jakarta: Bulan Bintang, 1973), h. 3 .

9 Muhaimin, Abdul Mujib, and Jusuf Mudzakkir, Studi Islam: Dalam Ragam Dimensi Dan Pendekatan (Jakarta: Kencana Prenata Media Group, 2014), h. 305.

${ }^{10}$ Muhaimin, Abdul Mujib, and Jusuf Mudzakkir, h. 305.

Volume 29 Nomor 1 Januari-Juni 2018 
4. Estetika yaitu filsafat tentang karya (kreasi) yang indah dan yang jelek

5. Epistemologi yaitu filsafat tentang ilmu pengetahuan

6. Filsafat-filsafat khusus seperti filsafat alam, filsafat agama dan lain-lain.

\section{Masuknya Filsafat ke dunia Islam}

Masuknya filsafat Yunani ke dunia Islam melalui berbagai hal antara lain:

\section{Perkembangan Pemikiran Yunani}

Pada sekitar abad VI SM, di Yunani kuno lahir beberapa tokoh pemikir yang terkenal seperti filosof pertama Thales pada tahun 640 SM, Anaximader, Anaximenes, dan Heraclitos yang hidup sekitar tahun 500 SM. ${ }^{11}$ Perkembangan pemikiran Yunani sekitar pada tahun 500-300 SM telah mencapai masa puncaknya sejak munculnya Socrates yang lahir di Athena pada tahun 470 SM dan meninggal pada tahun 399, Plato lahir pada tahun 427 dan meninggal pada 347 SM. Aristoteles lahir di Stagira Macedon pada tahun 384 SM meninggal pada tahun 322 SM, pada usia 17 tahun ia belajar ke Athena menjadi murid Plato. ${ }^{12}$

Pada akhir hidup Aristoteles, Alexander yang Agung mengalahkan Dairus pada tahun 331 SM, tetapi Alexander tidak menghancurkan kebudayaan Persi, melainkan menyatukan kebudayaan Persi dan Yunani. Setelah wafat, Alexander yang Agung, kerajaan yang besar itu terbagi menjadi tiga (3) yaitu: (1) Macedonia di Eropa; (2) Kerajaan Ptolemeus di Mesir dan Alexandria sebagai ibu kota; dan (3) Kerajaan seleucid (seleucus) di Asia dengan kota-kota penting Antioch di Syiria, Seleucia di Mesopotamia dan Bactra di Persi sebelah timur. ${ }^{13}$

Dari ketiga kerajaan itulah yang nantinya menjadi jembatan yang mewariskan pemikiran Yunani ke dunia Islam. Namun Mecedonia sendiri tampaknya tidak menjadi jembatan

${ }^{11}$ M.M. Sharif, ed., History of Muslim Philosophy (Wiesbaden: Otto Harrasowits, 1963), h. 13.

${ }^{12}$ Sharif, h. 99.

${ }^{13}$ Harun Nasution, Filsafat Dan Mistisisme Dalam Islam (Jakarta: Bulan Bintang, 1973), h. 10. 
langsung, tetapi ada satu kota di dekat Baghdad, Yakni Yundi Shapur.

\section{Kontak Tidak Sengaja}

Umat Islam tidak sengaja mencari filsafat Yunani untuk dipelajari. Masuknya filsafat Yunani dalam dunia Islam terjadi terjadi secara alamiah hasil dari interaksi antara masyarakat Islam dengan bangsa Syiria, Persia dengan wilayah lain yang secara tidak langsung telah membahas ilmu kedokteran dan kimia ke dalam Islam.

Pertama kali yang dipelajari oleh umat Islam adalah Ilmu Kedokteran. Ini terjadi pada masa khalifah Marwan bin Hakam (64-65 H) ketika dokter Maserqueh menerjemahkan kitab Pastur Ahran bin Ayun, yang berbahasa Suryani ke dalam bahasa Arab. Kitab ini disimpan di perpustakaan sampai masa pemerintahan Umar bin Abd al-Aziz (99-101 H). Umar bin Abd al-Aziz beristikharah dahulu untuk mengeluarkan kitab ini agar dimanfaatkan dan diambil faedahnya bagi umat Islam. Dalam riwayat lain ada yang mengatakan bahwa penerjemah yang pertama kali dalam Islam dilakukan oleh Khalid bin Yazid alAmawi $(85 \mathrm{H})$ yang memerintah menerjemahkan kitab-kitab kimia ke dalam bahasa Arab.

Jelasnya sejak awal pemerintahan Khulafaurrasyidin sampai Bani Umayyah, umat Islam sudah menguasai wilayahwilayah yang dahulu dikuasai bangsa Romawi, Persia dan pemikiran-pemikiran Yunani dapat dibaca oleh alim ulama Islam dan telah masuk dalam kalangan Islam, terutama di kalangan kaum Mu'tazilah sehingga dalam pembahasan teologi Islam mereka banyak dipengaruhi daya akal atau logika yang terdapat dalam falsafah Yunani.

\section{Masuknya Filsafat Yunani melalui Kegiatan Penerjemah}

Pada masa pemerintahan Bani Abbas, setelah pusat pemerintahan dipindah dari Damaskus Syiria ke Baghdad Irak, kegiatan penerjemah dilakukan secara besar-besaran dan ditangani secara serius. Khalifah Al-Makmum memprakarsai penerjemahan tersebut dengan dua alasan utama, yaitu; pertama,

${ }^{14}$ Ahmad Fuad Al-Ahwani, Al-Falsafah Al-Islamiyah (Kairo: Dar Al-Qolam, 1962), h. 39.

Volume 29 Nomor 1 Januari-Juni 2018 
banyaknya perdebatan mengenai soal-soal agama antara kaum muslimin di satu pihak dengan kaum Yahudi dan Nasrani di pihak lain. Untuk menghadapi perdebatan tersebut, mereka memerlukan filsafat Yunani agar dalil-dalil dan pengaturan alasan bisa disusun dengan sebaik-baiknya, sehingga mengimbangi lawan-lawannya yang terkenal memakai ilmu Yunani terutama logika; kedua, banyaknya kepercayaan dan pikiran-pikiran Iran yang masuk kepada kaum muslimin, orangorang Iran dalam menguatkan kepercayaan memakai ilmu berpikir yang didasarkan atas filsafat Yunani. ${ }^{1}$

Pada masa pemerintahan Bani Umayyah, karena perhatian banyak tertuju pada kebudayaan Arab, maka pengaruh itu baru nyata atau kelihatan pada masa Bani Abbas, karena yang berpengaruh di pusat pemerintahan bukan lagi orang Arab, tetapi orang-orang Persia, seperti keluarga Baramikan, yang telah lama berkecimpung dalam kebudayaan Yunani. ${ }^{16}$

Secara umum, penerjemahan filsafat Yunani ke dalam Islam terbagi dalam dua tahapan utama, yaitu: Pertama, penerjemahan secara tidak langsung, dalam arti filsafat Yunani diterjemahkan dalam bahasa Arab melalui tangan kedua, yaitu di bawah pengaruh Plotinus, Suriah, dan dari tangan-tangan para filosof di Yundi Shapur. Dalam terjemahan ini juga dilakukan oleh orang-orang ahli Bahasa Suryani, Syiria dan Persi yang kebanyakan para penerjemahnya terdiri dari orang-orang Nasrani. Kedua, setelah para ahli atau pemikir Islam mengenal filsafat Yunani lewat penerjemahan tersebut, mereka baru mengadakan pensyarahan yang pada giliran selanjutnya mampu melahirkan filosof muslim sendiri seperti: al-Kindi, al-Farabi, Ibnu Sina, Ibnu Rusyd, dan sebagainya.

Puncak penerjemahan tersebut terjadi pada masa khalifah al-Makmum yang pada tahun 215 Harun mendirikan Bait alHikmah, di mana para penerjemahnya dan pimpinannya ditangani oleh orang-orang yang menguasai bahasa Suryani, Yunani, dan bahasa Arab dengan baik, dan pimpinan Bait al-

\footnotetext{
${ }^{15}$ Hanafi, Islam Falsafah Agama, h. 64.

${ }^{16}$ Harun Nasution, Islam Ditinjau dari Berbagai Aspeknya (Jakarta: Bulan Bintang, 1974), h. 46.
} 
Hikmah ini dipegang oleh Hunai Ibn Ishaq. ${ }^{17}$ Para penerjemah banyak menerjemahkan filsafat Yunani dengan tiga pemikir utama yang banyak mempengaruhi para pemikir Islam yaitu plato, Aristoteles dan Neo-platonisme.

\section{Pendekatan Filosofis dalam Studi Islam}

Pengaruh filsafat Yunani membangkitkan umat Islam untuk mempelajari secara mendalam tidak hanya terbatas pada bidang filsafat dan bidang ilmu pengetahuan seperti ilmu kedokteran, kimia, astronomi dan matematika, tetapi sampai menyentuh ke seluruh aspek dalam pemikiran umat Islam seperti halnya ilmu kalam, fiqih, tafsir dan tasawuf. Seperti masuknya pengaruh filsafat dalam bidang ilmu kalam muncul persoalan tentang kedudukan akal di samping wahyu dalam menemukan kebenaran, apakah Tuhan mempunyai sifat atau tidak. Dalam bidang fiqih muncul persoalan yang sama apakah seseorang dapat menetapkan hukum berdasarkan pada ijtihad akal. Dalam bidang tafsir tentang penggunaan qiyas atau analogi, apakah seseorang dapat menafsirkan atau menakwilkan ayat. Kemudian dalam bidang tasawuf muncul persoalanpersoalan sekitar filsafat nilai, masalah martabat dalam tarekat yang dekat dengan masalah teori emanasi. ${ }^{18}$

Pengaruh filsafat juga melahirkan filosof-filosof muslim yang terkenal dalam dunia Barat dan Timur, seperti Al-Kindi, al-Farabi, Ibnu Sina, al-Ghazali, Ibnu Rusyd, Ibnu Bajah, Ibnu Thufail, Ikhwanushafa, Ibnu Maskawaih dan lain-lain. Selain itu juga membangkitkan revolusi berpikir dalam dunia Islam, walaupun tidak menutup kemungkinan adanya perbedaan pendapat. Perkembangan yang menarik adalah penolakan dan penerimaaan yang dilakukan oleh pemikir Islam terhadap pengaruh filsafat Yunani karena mereka sudah mempelajari secara mendalam terhadap filsafat tersebut. Al-Ghazali misalnya telah menolak hasil-hasil pemikiran filosof muslim yang didasarkan atas pemikiran Yunani, yang nyata-nyata bertentangan dengan ajaran Islam, dalam bukunya Tahafuth al-

\footnotetext{
${ }^{17}$ Al-Ahwani, Al-Falsafah Al-Islamiyah, h. 42.

${ }^{18}$ Sir Muhamad Iqbal, The Reconstruction of Religious Thougt in Islam (New Delhi: Nusrat Ali Nasri, 1981), h. 4. 
Falasifah. Selanjutnya Ibnu Rusyd membela filosof muslim dan menolak kesimpukan al-Ghazali dalam bukunya Tahafut alTahafut.

Pendekatan filosofis dalam kajian Islam berusaha untuk sampai kepada kesimpulan-kesimpulan yang universal dengan meneliti dari akar permasalahannya, metode ini bersifat mendasar dengan cara radikal dan integral karena memperbincangkan sesuatu dari segi esensi atau hakikat sesuatu. ${ }^{19}$ Pendekatan filosofis diibaratkan sebagai pisau analisis untuk membedah Islam secara mendalam, integral dan komprehensif untuk melahirkan pemahaman dan pemikiran tentang Islam yang senantiasa relevan pada setiap waktu dan ruang atau shalih fi kulli zaman wal makan. Filsafat berperan membuka wawasan berpikir umat dan digunakan sebagai pilar dalam merekonstruksi pemikiran dan membongkar formalisme agama dalam istilah M. Arkoun taqdis al-afkar al-diniyyah sebagai salah satu sumber ekslusivisme agama dan kejumudan umat. $^{20}$

Memahami agama melalui pendekatan filosofis agar dapat memberi makna terhadap sesuatu yang dijumpainya, menangkap hikmah, hakikat atau inti yang terkandung dalam ajaran agama, bisa dimengerti dan dipahami, sehingga dalam melakukan amal ibadah tidak merasa hampa, kekeringan spiritual serta menimbulkan kebosanan dalam menjalankannya. Selain itu juga dapat meningkatkan sikap, penghayatan juga daya spiritualitasnya sehingga tidak terjebak dalam pemahaman agama yang sekedar formalistik dan tidak menemukan nilai-nilai di dalamnya.

Pendekatan ini juga tidak menyepelekan bentuk ritual agama secara formal, filsafat digunakan untuk mempelajari dari segi batin yang bersifat esoterik, sedangkan bentuk formal memfokuskan segi lahiriahnya yang bersifat eksoterik. pendekatan yang demikian sebenarnya sudah banyak digunakan oleh para ahli seperti Muhammad Al-Jurjawi dalam bukunya

${ }^{19}$ Supiana, Metodologi Studi Islam (Jakarta: Ditjen Pendis Kemenag RI, 2012), h. 96.

${ }^{20}$ Husein Heriyanto, Nalar Saintifik Peradaban Islam (Bandung: Mizan, 2011), h. 355. 
Hikmah Al-Tasyri'wa Falsafatuhu buku tersebut berusaha mengungkapkan hikmah yang terdapat di balik ajaran-ajaran agama Islam. $^{21}$

Perintah dalam ajaran Islam dalam bentuk ibadah misalnya jika dipahami dengan pendekatan filosofis seperti shalat berjamaah hikmah yang terkandung di antaranya bisa merasakan hidup secara berdampingan dengan orang lain. Mengerjakan puasa agar seseorang dapat merasakan lapar dan menimbulkan rasa iba kepada sesamanya yang hidup serba kekurangan. Demikian pula ibadah haji dalam menunaikan rukun Islam dapat merasakan nilai-nilai spiritual yang terkandung di dalamnya, ibadah yang dilaksanakan di kota Makkah dalam waktu bersamaan dengan bentuk gerak ibadah (manasik) yang sama dengan yang dikerjakan lainnya dimaksudkan agar orang yang mengerjakan berpandangan luas, merasa bersaudara dengan sesama muslim dari seluruh dunia. Thawaf yang dikerjakan mengandung makna bahwa hidup harus penuh dengan dinamika yang tak kenal lelah, namun semuanya itu harus tertuju sebagai ibadah kepada Allah semata.

Mengerjakan sa'i yakni lari-lari kecil menggambarkan bahwa hidup tidak boleh putus ada, terus mencoba. Dimulai dari bukit Shafa yang artinya bersih dan berakhir pada bukit Marwa yang artinya berkembang. Dengan demikian hidup ini harus diisi dengan perjuangan yang didasarkan pada tujuan dan niat yang bersih sehingga dapat memperoleh keberkahan. Sementara itu wukuf di Arafah maksudnya adalah saling mengenal, yakni dapat mengenal siapa dirinya, mengenal tuhannya dan mengenal sesama saudaranya dari berbagai belahan dunia. Demikian pula melontar jumrah dimaksudkan agar seseorang dapat membuang sifat-sifat negatif yang ada dalam dirinya untuk diganti dengan sifat-sifat yang positif, mengenakan pakaian serba putih maksudnya adalah agar seseorang mengutamakan kesederhanaan, kesahajaaan dan serba bersih jiwahnya sehingga tidak terganggu hubunganya dengan tuhan.

${ }^{21}$ Abuddin Nata, Metodologi Studi Islam (Jakarta: RajaGrafindo Persada, 2008), h. 43.

Volume 29 Nomor 1 Januari-Juni 2018 
Demikian pula ketika kita membaca sejarah kehidupan para nabi terdahulu. Maksudnya bukan sekadar menjadi tontonan atau sekadar mengenangnya, tetapi bersamaan dengan itu diperlukan kemampuan menangkap makna filosofis yang terkandung di belakang peristiwa tersebut. Seperti kisah Nabi Yusuf yang digoda seorang wanita bangsawan, secara lahiriah memang menggambarkan kisah yang bertema pornografi atau kecabulan, pemahaman ini bisa terjadi manakala dipahami hanya dalam bentuk lahiriah dari kisah tersebut. Tetapi jika dipahami lebih mendalam makna sebenarnya dari kisah tersebut Tuhan ingin mengajarkan kepada manusia agar memiliki ketampanan lahiriah dan batiniah secara prima seperti Nabi Yusuf yang telah menunjukkan kesanggupannya dalam mengendalikan farjinya dari berbuat maksiat, sementara lahiriahnya ia tampan dan menyenangkan orang yang melihatnya. Makna demikian dapat dijumpai melalui pendekatan yang bersifat filosofis. ${ }^{22}$

Pentingnya pendekatan ini, pendekatan filsafat juga digunakan dalam memahami berbagai bidang lainnya selain agama. Misalnya filsafat hukum Islam, filsafat sejarah, filsafat kebudayaan, filsafat ekonomi, dan lain sebagainya. Pandangan filsafat yang bercorak perenialis seperti ini secara metodologis memberikan harapan segar terhadap dialog antara umat beragama, sebab melalui metode ini diharapkan tidak hanya sesama umat beragama dapat menemukan kesatuan agamaagama pada wilayah transenden, melainkan juga dapat mendiskusikan secara lebih mendalam, sehingga dapat terbuka kebenaran yang betul-betul benar, dan tersingkirlah kesesatan yang betul-betul sesat, meskipun tetap dalam lingkup kerelatifan.

\section{Penutup}

Islam sebagai agama yang banyak menyuruh penganutnya mempergunakan akal pikiran sudah dapat dipastikan sangat memerlukan pendekatan filosofis dalam memahami ajarannya, seperti contoh-contohnya yang telah dikemukakan di atas.

${ }^{22}$ Nata, h. 43-44. 
Memahami Islam... Oleh: M.Arif Khoiruddin

Meskipun secara teoretis bisa memberikan harapan dan kesejukan, namun secara luas belum dapat dipahami dan diterima kecuali oleh sekelompok kecil saja, terutama bagi kaum tradisionalis formalistis yang cenderung memahami agama terbatas pada ketetapan melaksanakan aturan-aturan formalistik dari pengalaman agama. 
Abdullah, M. Amin. Antologi Studi Islam: Teori \& Metodologi. Yogyakarta: Sunan Kalijaga Press, 2000.

. Islamic Studies Di Perguruan Tinggi: Pendekatan Integratif-Interkonektif. Yogyakarta: Pustaka Pelajar, 2006.

Al-Ahwani, Ahmad Fuad. Al-Falsafah Al-Islamiyah. Kairo: Dar Al-Qolam, 1962.

Connolly, Peter. Aneka Pendekatan Studi Agama terj Imam Khairi. Yogyakarta: LKIS, 2011.

Hanafi, Ahmad. Islam Falsafah Agama. Jakarta: Bulan Bintang, 1973.

Heriyanto, Husein. Nalar Saintifik Peradaban Islam. Bandung: Mizan, 2011.

Iqbal, Sir Muhamad. The Reconstruction of Religious Thougt in Islam. New Delhi: Nusrat Ali Nasri, 1981.

Muhaimin, Abdul Mujib, dan Jusuf Mudzakkir. Studi Islam: dalam Ragam Dimensi dan Pendekatan. Jakarta: Kencana Prenada Media Group, 2014.

Nasution, Harun. Falsafah Agama. Jakarta: Bulan Bintang, 1973.

- Filsafat dan Mistisisme dalam Islam. Jakarta: Bulan Bintang, 1973.

_. Islam Ditinjau dari Berbagai Aspeknya. Jakarta: Bulan Bintang, 1974.

Nata, Abuddin. Metodologi Studi Islam. Jakarta: RajaGrafindo Persada, 2008.

Poespoprodjo, W. Logika Sientifika Pengantar Dialektika dan Ilmu. Bandung: Remaja Rosdakarya, 1985. 
Saifuddin, Endang. Kuliah al-Islam, Pendidikan Agama Islam di Perguruan Tinggi. Bandung: Pustaka Salman ITB, 1980.

Sharif, M.M., ed. History of Muslim Philosophy. Wiesbaden: Otto Harrasowits, 1963.

Supiana. Metodologi Studi Islam. Jakarta: Ditjen Pendis Kemenag RI, 2012.

Syaibany, Omar Mohammad Al Toumy Al. Falsafah Pendidikan Islam. Diterjemahkan oleh Langgulung. Hoboken, NJ: JA Macfadden-Bartell Book, 1979.

Syaibany, Omar Mohammad Al Toumy Al. Filsafat Pendidikan Islam. Hoboken, NJ: JA Macfadden-Bartell Book, 1979.

Woodhouse, Mark B. A Preface to Philosophy. Belmont California: Wadsworth Publishing Company, 1984. 